\title{
Characterization of ethyl acetate and methanol extracts of Commiphora myrrha and evaluating in vitro anti-diabetic and anti-obesity activities
}

\author{
Heba Abdel-Hady*, Eman Ahmed El-Wakil, Eman Abdalla Morsi \\ Medicinal Chemistry Laboratory, Theodor Bilharz Research Institute, Kornish El-Nile-Warrak El-Hadar, Imbaba, Giza 12411, Egypt.
}

\begin{tabular}{l}
\hline ARTICLE INFO \\
\hline Received on: 20/03/2019 \\
Accepted on: 27/04/2019 \\
Available online: 01/09/2019 \\
\\
\hline Key words: \\
GC-MS gas chromatograph, \\
$\alpha$-amylase, $\alpha$-glucosidase, \\
Pancreatic lipase, flavonoids.
\end{tabular}

\begin{abstract}
Diabetes mellitus is a clinical disease categorized by hyperglycemia. Reduction of gastrointestinal glucose absorption through the inhibition of carbohydrate digesting enzymes is one of in vitro anti-diabetic therapeutic approach. This investigation aimed to estimate the in vitro anti-diabetic and anti-obesity activities for ethyl acetate and methanol extracts of Commiphora myrrha oleo-gum as well as the identification of the bioactive compounds. Commiphora myrrha was extracted with methanol and ethyl acetate. The two extracts were used to evaluate their $\alpha$-glucosidase, $\alpha$-amylase, and pancreatic lipase inhibitory activities. Identification of the bioactive compounds of ethyl acetate was analyzed by GC-MS (gas chromatography-mass spectrometry). The results showed that the ethyl acetate extract had a stronger inhibition activity on $\alpha$-amylase $\left(\mathrm{IC}_{50}=54.60 \mu \mathrm{g} / \mathrm{ml}\right)$ and $\alpha$-glucosidase $\left(\mathrm{IC}_{50}=58.7 \mu \mathrm{g} / \mathrm{ml}\right)$ than methanol extract on $\alpha$-amylase $\left(\mathrm{IC}_{50}=124.01 \mu \mathrm{g} / \mathrm{ml}\right)$ and $\alpha$-glucosidase $\left(\mathrm{IC}_{50}=191.2 \mu \mathrm{g} / \mathrm{ml}\right)$. Also, ethyl acetate extract had a promising inhibitory effect on pancreatic lipase $\left(\mathrm{IC}_{50}=107.8 \mu \mathrm{g} / \mathrm{ml}\right)$ than methanol extract $\left(\mathrm{IC}_{50}=498.1 \mu \mathrm{g} / \mathrm{ml}\right)$. GC-MS analysis of ethyl acetate extract identified 31 compounds. Among them nobiletin $(50.26 \%)$, metaproterenol (orciprenaline) (14.99\%), morantel (8.86\%), and tricetin (3.38\%) were the main compounds. These findings proved that $C$. myrrha has anti-diabetic and anti-obesity inhibition activity may be due to the bioactive compounds with interesting medicinal properties.
\end{abstract}

\section{INTRODUCTION}

Diabetes mellitus is a chronic health disorder that has been increased in the previous years and appreciated to be 439 million people by 2030. Diabetic patients demonstrated the risk in the incidence of several chronic health complications include obesity (Ahmad and Crandall, 2010). In this case, diabetes and obesity is a global health syndrome referred as diabesity (Tschop and DiMarchi, 2012).

$\alpha$-glucosidase, $\alpha$-amylase, and pancreatic lipase are enzymes secreted by lumen of small intestine, pancreas, and salivary glands (Tadera et al., 2006). They play an important

"Corresponding Author

Heba Abdel-Hady, Medicinal Chemistry Laboratory, Theodor Bilharz Research Institute, Kornish El-Nile-Warrak El-Hadar, Imbaba, Giza 12411,Egypt.E-mail: h_hady10@yahoo.com role in digestion of carbohydrates (degradation of starch and oligosaccharides to monosaccharaides) and glucose absorption, so in turn, inhibition of these enzymes causes reduction of postprandial blood glucose by decreasing the rate of glucose absorption and release in the small intestine (Hanhineva et al., 2010; Keskes et al., 2014; Narkhede et al., 2011). Also, a diet rich in fats and sedentary lifeway contributes the occurrence of type 2 diabetes, obesity, hyperlipidemia, and cardiovascular diseases (Cani et al., 2008; Etoundi et al., 2010; Liu et al., 2013).

However, one of anti-diabetic drugs strategy is to search for plants as $\alpha$-glucosidase and $\alpha$-amylase inhibitors as well as anti-obesity drugs (plants as pancreatic lipase inhibitors) (HasaniRanjbar et al., 2008; 2009).

Actually, many artificial drugs (acarbose and orlistat) are used broadly as inhibitors for mentioned enzymes but unfortunately they cause many side effects. Hence, many studies have been condensed to decrease their harmful effects by replacing those synthetic drugs with natural and safer inhibitors, which have fewer 
side effects and are desired more over than the synthetic drugs (Keskes et al., 2014; Mahalingam, 2017). So, large number of plants used as natural inhibitors owing to their active compounds as phenols and flavonoids which have been reported as effective inhibitors for these enzymes as garlic (Allium sativum), artichoke (Cynara scolymus), Rosmarinus officinalis, Apium graveolens, and Lavandula angustifolia (Allouche et al., 2004; Kasabri et al., 2017; Pereira et al., 2011).

Commiphora genus belongs to family Burseraceae include other than 200 species. It grows in tropical dry places as Africa, Arabia, and India (Gadir and Ahmed, 2014; Su et al., 2009). It produces many commercial resins; myrrh oleo-gum resin is one of them (Baser et al., 2003). These resins are yellow to red in color and always are covered with a dusty powder has a lighter color. However, true myrrh is produced by wounding Commiphora myrrha (Hosseinkhani et al., 2017). Myrrh has many effective medicinal uses and has been used to cure tumors, fever, disorders of gall bladder, dysmenorrhea, and skin infections (El Ashry et al., 2003; Massoud et al., 2001). Many previous investigations have been demonstrated the presence of many phytochemicals possess the mentioned biological activities as flavonoids, terpenoids, carbohydrates, lignans, steroids, and others (Shen et al., 2007).

Our study was designed to determine the $\alpha$-glucosidase and $\alpha$-amylase and pancreatic lipase inhibitory activity of $C$. myrrha methanol and ethyl acetate extracts as well as identification of the bioactive phytochemicals in the most active extract by GCMS analysis.

\section{MATERIALS AND METHODS}

\section{Chemicals and reagents}

$\alpha$-Amylase, $\alpha$-glucosidase (Saccharomyces cerevisiae), starch, and 3,5,di-Nitro salicylic acid (DNS) were purchased from Sigma-Aldrich, Bangalore. Sodium carbonate $\left(\mathrm{Na}_{2} \mathrm{CO}_{3}\right)$, P-Nitro-phenyl- $\alpha$-glucopyranoside (p-NPG), di-sodium hydrogen phosphate, and sodium dihydrogen phosphate were purchased from Hi-Media.

\section{Plant materials}

Commiphora myrrha oleo gum-resin was purchased from a local herbalist (Harraz Medicinal Plant Co., Ciaro, Egypt) and recognized by Dr. Rim Samir Hamdy, Prof. of Plant Taxonomy, Faculty of Science, Cairo University. Then, it was grounded into fine powder and kept in dark bottles until used at Medicinal Chemistry Dept., Theodor Bilharz Research Institute.

\section{Extraction of plant}

Nearly, $400 \mathrm{~g}$ of dried powder of C. myrrha was divided into two equal quantities ( $200 \mathrm{~g}$ ) and extracted with two different solvent; $85 \%$ methyl alcohol and ethyl acetate for 7 days, then filtered and concentrated with Rotatory Evaporator Buchi to obtain a crude methanol extract and the ethyl acetate extract.

\section{In-vitro anti-diabetic assays}

$\alpha$-Amylase inhibitory assay

$\alpha$-Amylase inhibition method was carried out with minor modification (Gayathri and Gayathri, 2014). The enzyme solution was equipped by melting $\alpha$-amylase in $20-\mathrm{mM}$ phosphate buffer $(6.9 \mathrm{pH})$ at concentration $0.5 \mathrm{mg} / \mathrm{ml}$. Nearly, $1 \mathrm{ml}$ of each extract at various concentrations ranged from 7.81 to $1,000 \mu \mathrm{g} /$ $\mathrm{ml}$ was added to $1 \mathrm{ml}$ of enzyme solution mixed together and kept warm at $25^{\circ} \mathrm{C}$ for 10 minutes. After that, $1-\mathrm{ml}$ starch $(0.5 \%)$ was added to the solution and kept warm again at $25^{\circ} \mathrm{C}$ for 10 minutes. The reaction stopped when $2-\mathrm{ml}$ di-Nitro salicylic acid was added (DNS color reagent), then heating the reaction mixture for 5 minutes in a water bath. Then cooled and the absorbance at $565 \mathrm{~nm}$ was measured using spectrophotometer. Acarbose was used with the same concentrations as a control. The experiment was carried out in triplets.

The inhibition \% was calculated by the equation:

$$
[(A c-A s) / A c] \times 100
$$

where, $A c$ is the absorbance of control and $A s$ is the absorbance of tested extract.

\section{$\alpha$-Glucosidase inhibitory assay}

$\alpha$-Glucosidase inhibition method was carried out with minor modification (Shai et al., 2011). In this method, the enzyme was equipped by melting $\alpha$-Glucosidase in $50 \mu \mathrm{l}$ of phosphate buffer $(100 \mathrm{mM}, 6.9 \mathrm{pH})$. Nearly, $20 \mu \mathrm{l}$ of each extract at various concentrations ranged from 7.8 to $1,000 \mu \mathrm{g} / \mathrm{ml}$ was added to $10 \mu \mathrm{l}$ of enzyme solution and incubated for 15 minutes at $37^{\circ} \mathrm{C}$. Then, 20 $\mu 1$ of 5-mM P-NPG was added as a substrate and incubated again at $37^{\circ} \mathrm{C}$ for 20 minutes. The reaction was stopped by adding $50 \mu \mathrm{l}$ of $\mathrm{Na}_{2} \mathrm{CO}_{3}(0.1 \mathrm{M})$. The absorbance of the released p-nitrophenol was measured at $405 \mathrm{~nm}$ using multi-plate Reader. Acarbose was used with the same concentrations as a control. The experiment was carried out in triplets.

The inhibition \% was calculated by the equation:

$$
[(A c-A s) / A c] \times 100
$$

where, $A c$ is the absorbance of control and $A s$ is the absorbance of tested extract.

\section{In vitro anti-obesity using pancreatic lipase inhibitory assay}

The lipase inhibition activity of plant extract was measured by the method proposed by Kim et al. (2010). In this assay, the porcine pancreatic lipase activity was measured using p-nitrophenyl butyrate (NPB) as a substrate. Lipase solution (100 $\mu \mathrm{g} / \mathrm{ml})$ was prepared in a $0.1-\mathrm{mM}$ potassium phosphate buffer $(\mathrm{pH}$ 6.0). In this assay, extracts with different concentrations ranged from 7.81 to $1,000 \mu \mathrm{g} / \mathrm{ml}$ were pre-incubated with $100 \mu \mathrm{g} / \mathrm{ml}$ of lipase for 10 minutes at $37^{\circ} \mathrm{C}$. The reaction was then started by adding 0.1-ml NPB substrate. The amount of p-nitrophenol released in the reaction was measured using Multi-plate Reader after incubation at $37^{\circ} \mathrm{C}$ for 15 minutes. Orlistat was used with the same concentrations as a control. Each experiment was performed in triplets. The data were expressed as percentage inhibition, which was calculated using the formula, Inhibitory activity $(\%)=$ $(1-A s / A c) \times 100$ where, $A s$ is the absorbance in the presence of the test substance and $A c$ is the absorbance of control.

\section{Inhibitory concentration $\mathbf{5 0 \%}$ (IC50) value calculation}

The concentration of the extract or drug which inhibits $50 \%$ of enzyme activity is termed as the $\mathrm{IC}_{50}$. Acarbose and orlistat were used as controls. A standard dose response curve was plotted 
at all the different concentrations. From the plotted curves, the $\mathrm{IC}_{50}$ value for each of the extract was calculated.

\section{Data analysis}

The data were combined and identified as mean \pm standard deviation (SD). $\mathrm{IC}_{50}$ values were calculated by SPSS software.

\section{GC-MS analysis}

The crude ethyl acetate extract of C. myrrha was injected to GC-MS technique. It was carried out using a GC (Agilent Technologies 7890A) interfaced with a mass-selective detector (MSD, Agilent 7000) equipped with a polar Agilent HP-5ms (5\%-phenyl methyl poly siloxane) capillary column (30 $\mathrm{m} \times 0.25 \mathrm{~mm}$ i.d. and $0.25 \mathrm{Elm}$ film thickness). The carrier gas was helium with the linear velocity of $1 \mathrm{ml} /$ minute. The injector and detector temperatures were $200^{\circ} \mathrm{C}$ and $250^{\circ} \mathrm{C}$, respectively. Injection mode, split; split ratio 1:10, volume injected $1 \mu \mathrm{l}$ of the sample. The MS operating parameters were as follows: ionization potential $70 \mathrm{eV}$, interface temperature $250^{\circ} \mathrm{C}$, and acquisition mass range 50-600. The identification of components was based on a comparison of their mass spectra and retention time (RT) with those of the authentic compounds and by computer matching with NIST and WILEY libraries as well as by comparison of the

Table 1. Inhibition assay of $\alpha$-amylase activity of $C$. myrrha extracts at different concentrations.

\begin{tabular}{cccc}
\hline \multirow{2}{*}{$\begin{array}{c}\text { Concentration } \\
(\mu \mathrm{g} / \mathrm{ml})\end{array}$} & $\begin{array}{c}\text { Standard drug } \\
\text { Acarbose }\end{array}$ & Ethyl acetate & Methanol \\
\cline { 2 - 4 } & $37.81 \pm 1.2$ & $22.75 \pm 1.2$ & $15.32 \pm 1.2$ \\
\hline 7.81 & $40.75 \pm 1.5$ & $31.25 \pm 2.1$ & $20.17 \pm 2.1$ \\
15.63 & $48.84 \pm 1.2$ & $44.37 \pm 0.58$ & $31.58 \pm 1.5$ \\
31.25 & $59.31 \pm 1.5$ & $51.91 \pm 1.3$ & $44.38 \pm 1.3$ \\
62.5 & $60.17 \pm 0.63$ & $59.41 \pm 0.58$ & $50.09 \pm 0.58$ \\
125 & $69.37 \pm 1.2$ & $66.73 \pm 0.63$ & $57.14 \pm 1.5$ \\
250 & $80.14 \pm 0.58$ & $70.58 \pm 2.1$ & $66.32 \pm 0.72$ \\
500 & $86.32 \pm 0.63$ & $76.35 \pm 1.2$ & $71.32 \pm 0.58$ \\
\hline
\end{tabular}

Data was represented as mean $\pm \mathrm{SD}$.

Table 2. Inhibition assay of $\alpha$-glucosidase activity of $C$. myrrha extracts at different concentrations.

\begin{tabular}{cccc}
\hline \multirow{2}{*}{$\begin{array}{c}\text { Concentration } \\
(\mu \mathrm{g} / \mathrm{ml})\end{array}$} & $\begin{array}{c}\text { Standard drug } \\
\text { Acarbose }\end{array}$ & Ethyl acetate & Methanol \\
\cline { 2 - 4 } & $32.15 \pm 0.58$ & $21.84 \pm 2.1$ & $14.63 \pm 0.72$ \\
\hline 7.81 & $43.28 \pm 1.2$ & $29.87 \pm 1.5$ & $21.97 \pm 1.2$ \\
15.63 & $50.31 \pm 1.5$ & $39.92 \pm 0.58$ & $30.17 \pm 1.5$ \\
31.25 & $60.14 \pm 0.72$ & $51.38 \pm 0.72$ & $38.95 \pm 1.3$ \\
62.5 & $63.42 \pm 2.1$ & $55.89 \pm 0.58$ & $48.38 \pm 0.63$ \\
125 & $71.34 \pm 1.5$ & $59.37 \pm 1.3$ & $51.44 \pm 0.58$ \\
250 & $86.34 \pm 1.2$ & $62.71 \pm 2.1$ & $55.67 \pm 2.1$ \\
500 & $90.10 \pm 0.58$ & $69.38 \pm 1.5$ & $58.34 \pm 1.5$ \\
\hline
\end{tabular}

Data was represented as mean $\pm \mathrm{SD}$. fragmentation pattern of the mass spectral data with those reported in the literature.

\section{RESULTS AND DISCUSSION}

\section{In vitro anti-diabetic assays}

The inhibitory activity of methanol and ethyl acetate extracts of $C$. myrrha on $\alpha$-amylase and $\alpha$-glucosidase enzymes was shown in Tables 1 and 2). The results demonstrated that the plant showed $\alpha$-amylase inhibition activity in a concentration dependent-manner. The ethyl acetate extract showed higher inhibitory activity than the methanol extract as its inhibition \% ranged from $22.75 \% \pm 1.20 \%$ to $76.35 \% \pm 1.20 \%$ from the lowest to the highest concentration $(7.81-1,000 \mu \mathrm{g} / \mathrm{ml})$, while methanol extract ranged from $15.32 \% \pm 0.58 \%$ to $71.32 \% \pm 1.2 \%$ from lowest to highest concentration. The maximum inhibition $\%$ is for Acarbose was found to be $37.81 \% \pm 1.2 \%$ to $86.32 \% \pm 0.63 \%$ from lowest to highest concentration. Regarding to $\alpha$-glucosidase, also, the ethyl acetate extract has higher inhibition activity than methanol extract as ranged from $21.84 \% \pm 2.10 \%$ to $69.38 \% \pm$ $1.50 \%$ from lowest to highest concentration, while methanol extract ranged from $14.63 \% \pm 0.72 \%$ to $58.34 \% \pm 1.5 \%$ from lowest to highest concentration. Also, Acarbose had the maximum inhibition $\%$ ranged from $32.15 \% \pm 0.58 \%$ to $90.10 \%$ in the same manner of concentrations. This activity may be returned to the

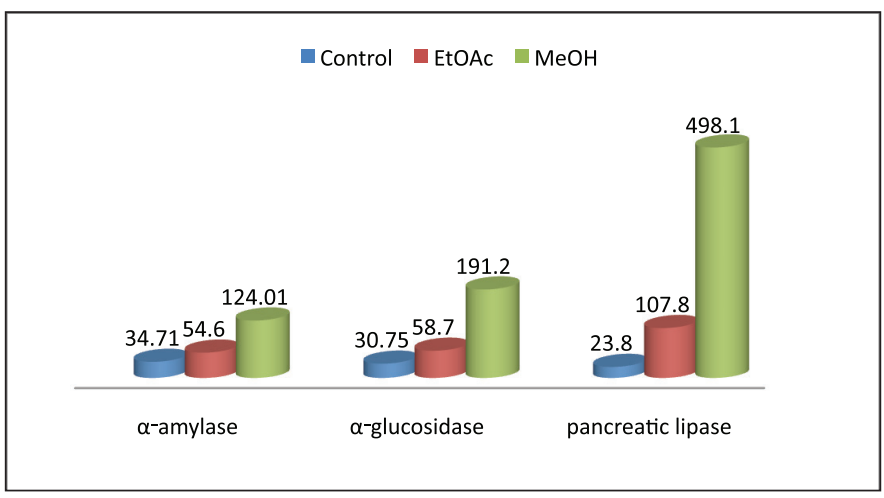

Figure 1. IC50 of Commiphora myrrha extracts in comparison with controls as anti-diabetic and anti-obesity inhibitors.

Table 3. Inhibition assay of pancreatic lipase activity of C. myrrha extracts at different concentrations.

\begin{tabular}{cccc}
\hline \multirow{2}{*}{$\begin{array}{c}\text { Concentration } \\
(\mu \mathrm{g} / \mathrm{ml})\end{array}$} & $\begin{array}{c}\text { Standard drug } \\
\text { Orlistat }\end{array}$ & Ethyl acetate & Methanol \\
\cline { 2 - 4 } & $29.31 \pm 1.4$ & $9.35 \pm 1.2$ & ---- \\
\hline 7.81 & $45.25 \pm 3.1$ & $18.98 \pm 0.63$ & ---- \\
15.63 & $54.36 \pm 2.6$ & $29.35 \pm 1.5$ & ----- \\
31.25 & $60.35 \pm 2.1$ & $43.67 \pm 0.72$ & $6.37 \pm 1.3$ \\
62.5 & $65.34 \pm 1.5$ & $52.41 \pm 2.1$ & $16.35 \pm 0.73$ \\
125 & $80.12 \pm 0.58$ & $57.32 \pm 1.5$ & $32.16 \pm 1.2$ \\
250 & $86.35 \pm 2.1$ & $61.32 \pm 0.63$ & $50.14 \pm 0.92$ \\
500 & $93.25 \pm 1.5$ & $67.35 \pm 2.1$ & $56.32 \pm 1.5$ \\
1000 & & & \\
\hline
\end{tabular}

Data was represented as mean $\pm \mathrm{SD}$. 
Table 4. GC-mass ethyl acetate of C. myrrha.

\begin{tabular}{|c|c|c|c|c|c|c|c|c|}
\hline Peak no. & Rt & Area \% & MF & MW & Components & Compound Nature & Common biological activity & References \\
\hline 1 & 3.94 & 0.57 & $\mathrm{C}_{10} \mathrm{H}_{8} \mathrm{O}_{2}$ & 160 & 6-Methylchromone & Hydrocarbon & Antimicrobial activity & (Flores et al., 2014) \\
\hline 2 & 7.69 & 0.55 & $\mathrm{C}_{8} \mathrm{H}_{13} \mathrm{NO}$ & 139 & Tropinon & Alkaloid & $\begin{array}{l}\text { Treating II type diabetes } \\
\text { mellitus }\end{array}$ & (Segre et al., 2015) \\
\hline 3 & 9.21 & 14.39 & $\mathrm{C}_{11} \mathrm{H}_{17} \mathrm{NO}_{3}$ & 211 & Metaproterenol (orciprenaline) & $\begin{array}{l}\text { Adenosine Sulfate } \\
\text { salt }\end{array}$ & $\begin{array}{l}\text { Orciprenaline drug Lung } \\
\text { Problems }\end{array}$ & (Ullah et al., 2017) \\
\hline 4 & 9.51 & 50.26 & $\mathrm{C}_{21} \mathrm{H}_{22} \mathrm{O}_{8}$ & 402 & Nobiletin & Flavonoid & $\begin{array}{l}\text { Anti-inflammatory, Anti-cancer } \\
\text { And Cholesterol lowering }\end{array}$ & (Huang et al., 2016) \\
\hline 5 & 10.37 & 0.64 & $\mathrm{C}_{15} \mathrm{H}_{32}$ & 212 & 2,6,11-Trimethyldodecane & Sesquiterpene & $\begin{array}{l}\text { Anti-oxidant, antinoceptive and } \\
\text { anti-inflammatory activities }\end{array}$ & (Haloui et al., 2010) \\
\hline 6 & 10.42 & 0.58 & $\mathrm{C}_{14} \mathrm{H}_{22} \mathrm{O}$ & 206 & 3,5-di-tert-butylphenol & Alkylated phenol & $\begin{array}{l}\text { Antioxidant activity against } \\
\text { LDL-oxidation }\end{array}$ & (Kusch et al., 2011) \\
\hline 7 & 10.47 & 0.77 & C19H18O6 & 342 & 3,7,8,4'-Tetramethoxyflavone & Flavonoid & Powerful antiallergic & (Sato and Tamura, 2015) \\
\hline 8 & 11.09 & 1.2 & $\mathrm{C}_{9} \mathrm{H}_{12} \mathrm{~N}_{4} \mathrm{O}_{3}$ & 224 & Temorin (Theacrine) & Alkaloid & $\begin{array}{l}\text { Anti-inflammatory and } \\
\text { analgesic effects }\end{array}$ & (Wang et al., 2011) \\
\hline 9 & 11.16 & 0.68 & $\mathrm{C}_{13} \mathrm{H}_{14} \mathrm{O}_{9}$ & 314 & $\begin{array}{l}\text { Salicylic acid - } \beta \text { - D- O- } \\
\text { glucuronide }\end{array}$ & $\begin{array}{l}\text { Phenolic } \\
\text { glucuronide }\end{array}$ & Anti-inflammatory & (Kuehl et al., 2004) \\
\hline 10 & 11.38 & 0.52 & $\mathrm{C}_{22} \mathrm{H}_{30} \mathrm{O}_{2} \mathrm{~S}$ & 358.5 & Santonox & $\begin{array}{l}\text { Epoxyanhydride } \\
\text { resin }\end{array}$ & Antioxidant standard & (Ho et al., 2013) \\
\hline 11 & 11.7 & 0.63 & $\mathrm{C}_{23} \mathrm{H}_{34} \mathrm{O}_{2}$ & 342.5 & Cannabidiol dimethyl ether & $\begin{array}{l}\text { Cannabinoid } \\
\text { derivative }\end{array}$ & Treatment of atherosclerosis. & (Takeda et al., 2011) \\
\hline 12 & 11.93 & 0.58 & $\mathrm{C}_{21} \mathrm{H}_{22} \mathrm{O}_{11}$ & 450 & Astilbin & Flavonoid & Antibacterial activity & (Moulari et al., 2006) \\
\hline 13 & 12.57 & 1.54 & $\mathrm{C}_{10} \mathrm{H}_{20} \mathrm{O}$ & 156 & $\beta$-Citronellol & Monoterpenoid & Neuroprotective activity & (de Sousa et al., 2006) \\
\hline 14 & 12.64 & 0.53 & $\mathrm{C}_{15} \mathrm{H}_{24} \mathrm{O}$ & 220 & Spathulenol & Sesquiterpene & $\begin{array}{l}\text { Antioxidant, anti-inflammatory, } \\
\text { antiproliferative and } \\
\text { antimycobacterial activities }\end{array}$ & (do Nascimento et al., 2018) \\
\hline 15 & 12.73 & 0.56 & $\mathrm{C}_{15} \mathrm{H}_{24}$ & 204 & Selinene & Sesquiterpene & Antimicrobial activity & (Wetwitayaklung et al., 2009) \\
\hline 16 & 12.78 & 0.63 & $\mathrm{C}_{20} \mathrm{H}_{32}$ & 272 & Cembrene & Diterpene & $\begin{array}{l}\text { Anti-tumor and anti- } \\
\text { inflammatory }\end{array}$ & (Hegazy et al., 2017) \\
\hline 17 & 12.91 & 0.71 & $\mathrm{C}_{15} \mathrm{H}_{24} \mathrm{O}$ & 220 & Caryophyllene oxide & Sesquiterpene & $\begin{array}{l}\text { Anticancer and analgesic } \\
\text { activities }\end{array}$ & (Fidyt et al., 2016) \\
\hline 18 & 13.07 & 0.59 & $\mathrm{C}_{15} \mathrm{H}_{26} \mathrm{O}_{2}$ & 238 & Geranyl isovalerate & Sesquiterpene & Antimicrobial activity & (Al-Qudah, 2013) \\
\hline \multirow[t]{2}{*}{19} & \multirow[t]{2}{*}{13.3} & \multirow[t]{2}{*}{0.53} & \multirow[t]{2}{*}{$\mathrm{C}_{15} \mathrm{H}_{24}$} & \multirow[t]{2}{*}{204} & \multirow[t]{2}{*}{ Ledene oxide } & \multirow[t]{2}{*}{ Sesquiterpene } & $\begin{array}{l}\text { Anti-tumor, Analgesic } \\
\text { Antibacterial, }\end{array}$ & \multirow[t]{2}{*}{ (Alagammal et al., 2012) } \\
\hline & & & & & & & Anti-inflammatory & \\
\hline 20 & 13.37 & 0.59 & $\mathrm{C}_{15} \mathrm{H}_{24} \mathrm{O}_{2}$ & 236 & Corymbolone & Sesquiterpene & Antibacterial & (Zhang et al., 2017) \\
\hline 21 & 13.54 & 3.38 & $\mathrm{C}_{15} \mathrm{H}_{10} \mathrm{O}_{7}$ & 302 & Tricetin & Flavonoid & Anticancer & (Chien et al., 2017) \\
\hline 22 & 13.86 & 0.74 & $\mathrm{C}_{12} \mathrm{H}_{10} \mathrm{O}_{2} \mathrm{~S}$ & 218 & Thiobisphenol & Bisphenol & Antioxidant & (Yamamura et al., 1995) \\
\hline 23 & 13.92 & 1.36 & $\mathrm{C}_{16} \mathrm{H}_{12} \mathrm{O}_{6}$ & 300 & Geraldol & Flavonoid & Anticancer and antiangiogenic & (Touil et al., 2011) \\
\hline 24 & 14.04 & 1.51 & $\mathrm{C}_{18} \mathrm{H}_{22} \mathrm{O}_{2}$ & 270 & Estrone & Steroid & Natural hormone & (Schäfer et al., 2003) \\
\hline 25 & 14.11 & 0.6 & $\mathrm{C} 20 \mathrm{H} 30 \mathrm{O}$ & 286 & Retinol & Vitamin A & $\begin{array}{l}\text { Anti-microbial and treating } \\
\text { skin-related diseases }\end{array}$ & (Feneran et al., 2011) \\
\hline 26 & 14.45 & 1.09 & $\mathrm{C}_{21} \mathrm{H}_{20} \mathrm{O}_{10}$ & 432 & Vitexin & Flavone glycoside & Anti-inflammatory effect & (Nikfarjam et al., 2017) \\
\hline 27 & 15.17 & 2.35 & $\mathrm{C}_{21} \mathrm{H}_{44} \mathrm{O}$ & 312.5 & Heneicosanol & Fatty alcohol & Anti-microbiological activity & (Balachandar et al., 2018) \\
\hline 28 & 16.74 & 0.73 & $\mathrm{C}_{15} \mathrm{H}_{32} \mathrm{O}$ & 228 & Hexahydrofarnesol & $\begin{array}{l}\text { Sesquiterpene } \\
\text { alcohol }\end{array}$ & Anti-microbiological activity & (Liolios et al., 2007) \\
\hline 29 & 18.1 & 8.86 & $\mathrm{C}_{12} \mathrm{H}_{16} \mathrm{~N}_{2} \mathrm{~S}$ & 220 & Morantel & Heterocyclic & $\begin{array}{l}\text { Anthelmintic drug removal of } \\
\text { parasitic worms in livestock }\end{array}$ & (Enejoh and Suleiman, 2017) \\
\hline 30 & 21.09 & 0.57 & $\mathrm{C} 12 \mathrm{H} 14 \mathrm{O} 5$ & 238 & Methyl Sinapate & Phenolic acid & $\begin{array}{l}\text { Antioxidant, antimicrobial, } \\
\text { anti-inflammatory, and } \\
\text { anticancer }\end{array}$ & $\begin{array}{l}\text { (Nićiforović and Abramovič } \\
\text { 2014) }\end{array}$ \\
\hline 31 & 21.94 & 1.77 & C19H18O5 & 326 & $\begin{array}{l}\text { 3-(3,4- dimethoxyphenyl)-7- } \\
\text { methoxy-4-methylcoumarin }\end{array}$ & Coumarin & Antiinflammatory & (Ouf et al., 2015) \\
\hline \multicolumn{2}{|c|}{ Total } & 100.1 & & & & & & \\
\hline
\end{tabular}



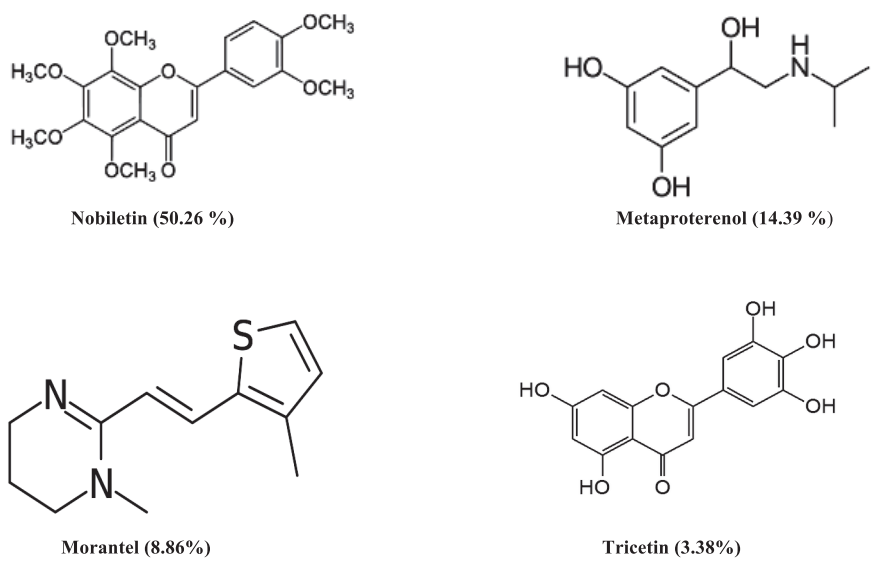

Figure 2. The structure of main constituents of ethyl acetate $C$. myrrha extract.

presence of phytochemicals, which are strong enzyme inhibitors. The $\mathrm{IC}_{50}$ values for both extracts are comparable with that of Acarbose (Fig. 1).

The inhibitory activity of C. myrrha is in a full agreement with other studies reported the inhibition activity of medicinal plants as black and green teas on enzymes (Zhang and Kashket, 1998), Allium species (Nickavar and Yousefian, 2010) and also, white and red ginger on both enzymes (Oboh et al., 2010). As well as, previous studies recommended using of eggplant phenolics as a diet to manage type-II diabetes (Oboh et al., 2010). So, our finding revealed that $C$. myrrha can be used as a natural inhibitor to reduce post-prandial hyperglycemia. This anti-diabetic inhibitory activity of ethyl acetate extract may be connected to the major compounds that identified in the extract as reported by previous studies on medicinal plants (Al-Hallaq et al., 2013; Habtemariam, 2012).

\section{In vitro anti-obesity assay}

The inhibitory activity of methanol and ethyl acetate extracts of $C$. myrrha on pancreatic lipase enzyme was shown in Table 3. The results revealed that the ethyl acetate extract showed higher inhibitory activity than the methanol extract as its inhibition $\%$ ranged from $9.35 \% \pm 1.2 \%$ to $67.35 \% \pm 2.10 \%$ from the lowest to the highest concentration $(7.81-1,000 \mu \mathrm{g} / \mathrm{ml})$, while methanol extract neglected at the small concentrations while ranged from $6.37 \% \pm$ $1.3 \%$ to $56.32 \% \pm 1.5 \%$ from lowest to highest concentration. The maximum inhibition $\%$ is for orlistat was found to be $29.31 \% \pm 1.4 \%$ to $93.25 \% \pm 1.5 \%$ from lowest to highest concentration. The $\mathrm{IC}_{50}$ values for both extracts are comparable with that of orlistat (Fig. 1). This activity may be due to the identified compounds from ethyl acetate extract as it has been reported that polyphenol compounds in the plants responsible for the anti-obesity and anti-diabetic inhibition activity (Lei et al., 2007; Yajima et al., 2005). However, our results agreed with other previous reports showed the inhibition activity of many medicinal plants on pancreatic lipase (Birari and Bhutani, 2007; Sharma et al., 2005).

\section{GC-MS analysis}

Our results proved that the ethyl acetate extract has the highest inhibitory activity and can be used as anti-diabetic and antiobesity drugs. Therefore, we analyzed it by GC-MS to identify the phytochemicals may be responsible for its activity. Results of GCMS show the different flavonoid compounds in the ethyl acetate of C. myrrha, such as alkaloid, coumarin, vitamin $\mathrm{A}_{1}$, analogue pyrantel, phenolic acid, steroid, monoterpene, sesquiterpene, and diterpene which have therapeutic aspects. GC-MS analysis of $C$. myrrha showed 31 compounds as shown in Table 4 and Figure 2. The characterization of the components of the extract was fulfilled by their RT, molecular weight (MW), molecular formula (MF), concentration (\%) also, common biological activity and the nature and of each compound. These compounds are listed according to their RTs.

The results demonstrated that the extract is rich with flavonoid compounds (57.44\%) which have been known as an effective inhibitor for diabetes and obesity enzymes (Jung et al., 2014; Testa et al., 2016). The main compound of flavonoids is Nobiletin (50.26\%); a polymethoxylated flavone; which has antiinflammatory, anti-cancer, and cholesterol lowering. Also, other previous studies have been shown that it improves adiposity, dyslipidemia, hyperglycemia, and insulin resistance (Huang et al., 2016; Lee et al., 2013).

There is another dietary flavonoid is Tricetin $(3.38 \%)$ which has anti-microbial effect, anti-oxidant activity, cytostatic properties, and anti-metastatic activity in various solid tumors including breast, liver, lung, bone, and brain tumors (Chien et al., 2017). Furthermore, the previous studies have been displayed the strongest $\alpha$-glucosidase inhibition effect of this compound with comparison to the anti-diabetic acarbose drug $(\mathrm{Wu}$ and Tian, 2018).

Metaproterenol (14.39\%) has been known as orciprenaline in other countries. It has been used as drug to treat lung problems (such as: asthma, bronchitis, and emphysema). Also, it is a bronchodilator works by orally inhaling devices to open the breathing passage (Ullah et al., 2017). This compound has not been separated previously from plant extract but it has already manufactured as drug named (Alupent). Furthermore, Morantel (8.86\%) known as Anthelmintic drug used against larval stages and adult gut worms that dwell in the lumen of intestine and/or its mucosal surface (Dyary, 2016; Enejoh and Suleiman, 2017).

There are different sesquiterpene compounds $(4.88 \%)$ which have anti-oxidant, anti-inflammation, anti-proliferative, and anti-mycobacterial activities (do Nascimento et al., 2018). However, these compounds may be meaningful to anti-diabetic and anti-obesity inhibitory activity of $C$. myrrha ethyl acetate extract.

\section{CONCLUSION}

This study demonstrated that the ethyl acetate extract of C. myrrha has anti-diabetic and anti-obesity inhibition activity and was rich in compounds that play an important role in therapy of hyperglycemia and obesity. Therefore, encourage to use this plant due to its effect is recommended to diabesity patients.

\section{REFERENCES}

Ahmad LA, Crandall JP. Type 2 diabetes prevention: a review. Clin Diabetes, 2010; 28(2):53-9.

Alagammal M, Tresina PS, Mohan VR. GC-MS determination of bioactive components of Polygala javana dc. Int J Curr Pharm Res, 2012; $4(2): 42-4$. 
Al-Hallaq EK, Kasabri V, Abdalla SS, Bustanji YK, Afifi FU. Anti-obesity and anti-hyperglycemic effects of Crataegus aronia extracts: in vitro and in vivo evaluations. Food Nutr Sci, 2013; 4:972-83.

Allouche N, Fki I, Sayadi S. Toward a high yield recovery of anti-oxidants and purified hydroxytyrosol from olive mill wastewaters. J Agric Food Chem, 2004; 52:267-73.

Al-Qudah MA. Chemical composition and antimicrobial activity of the essential oil of Linum pubescens growing wild in Jordan. Nat Pro Res, 2013; 27(12):1141-4.

Balachandar R, Karmegam N, Saravanan M, Subbaiya R, Gurumoorthy P. Synthesis of bioactive compounds from vermicast isolated actinomycetes species and its anti-microbial activity against human pathogenic bacteria. Microb Path, 2018; 121:155-65.

Baser KHC, Demirci B, Dekebo A, Dagne E. Essential oils of some Boswellia spp., myrrh and opopanax. Flavour Frag J, 2003; 18:153-6.

Birari RB, Bhutani KK. Pancreatic lipase inhibitors from natural sources: unexplored potential. Drug Discov Today, 2007; 12:879-89.

Cani PD, Bibiloni R, Knauf C, Waget A, Neyrinck AM, Delzenne NM, Burcelin R. Changes in gut microbiota control metabolic endotoxemia-induced inflammation in high-fat diet-induced obesity and diabetes in mice. Diabetes, 2008; 57(6):1470-81.

Chien MH, Chow JM, Lee WJ, Chen HY, Tan P, Wen YC, Lin YW, Hsiao PC, Yang SF. Tricetin induces apoptosis of human leukemic HL-60 cells through a reactive oxygen species-mediated c-Jun N-terminal kinase activation pathway. Int J Mol Sci, 2017; 18(8):1-14.

de Sousa DP, Gonçalves JCR, Quintans-Júnior L, Cruz JS, Araújo DAM, de Almeida RN. Study of anti-convulsant effect of citronellol, a monoterpene alcohol, in rodents. Neurosci Lett, 2006; 401(3):231-5.

do Nascimento KF, Moreira FMF, Santos JA, Kassuya CAL, Croda JHR, Cardoso CAL, do Carmo Vieira M, Ruiz AL, Foglio MA, de Carvalho JE, Formagio AS. Antioxidant, anti-inflammatory, antiproliferative and antimycobacterial activities of the essential oil of Psidium guineense Sw. and spathulenol. J Ethnopharmacol, 2018; 210:351-8.

Dyary HO. Veterinary anthelmintics and anthelmintic drug resistance. J Zankoy Sulaimani Part A, 2016; 18(1):191-206.

El Ashry ES, Rashed N, Salama OM, Saleh A. Components, therapeutic value and uses of myrrh. Pharmazie, 2003; 58(3):163-8.

Enejoh OS, Suleiman MM. Anthelmintics and their application in veterinary medicine. Res Med Eng Sci, 2017; 2:1-10.

Etoundi CB, Kuaté D, Ngondi JL, Oben J. Anti-amylase, antilipase and antioxidant effects of aqueous extracts of some Cameroonian spices. J Nat Products, 2010; 3:165-71.

Feneran AN, Kaufman WS, Dabade TS, Feldman SR. Retinoid plus antimicrobial combination treatments for acne. Clin Cosmetic Invest Derma, 2011; 4:79.

Fidyt K, Fiedorowicz A, Strządała L, Szumny A. $\beta$-caryophyllene and $\beta$-caryophyllene oxide- natural compounds of anticancer and analgesic properties. Cancer Med, 2016; 5(10):3007-17.

Flores H, Ximello A, Camarillo EA, Amador P. The standard molar enthalpies of formation of chromone-3-carboxylic acid, 6-methylchromone2-carboxylic acid, and 6-methyl-4-chromanone determined by microcombustion calorimetry. J Therm Analysis Calorimetry, 2014; 117(1):433-

Gadir SA, Ahmed IM. Commiphora myrrha and commiphora Africana essential oils. J Chem Pharm Res, 2014; 6(7):151-6.

Gayathri GA, Gayathri M. Preliminary qualitative phytochemical screening and in vitro hypoglycemic potential of Acanthus ilicifolius and Evolvulus emerginatus. Int J Pharm Pharm Sci, 2014; 6:362-5.

Habtemariam S. The anti-obesity potential of sigmoidin A. Pharm Biol, 2012; 50:1519-22.

Haloui E, Marzouk Z, Marzouk B, Bouftira I, Bouraoui A, Fenina N. Pharmacological activities and chemical composition of the Olea europaea L. leaf essential oils from Tunisia. J Food Agr Environ, 2010; $8(2): 204-8$
Hanhineva K, Törrönen R, Bondia-Pons I, Pekkinen J, Kolehmainen M, Mykkänen H, Poutanen K. Impact of dietary polyphenols on carbohydrate metabolism. Int J Mol Sci, 2010; 11(4):1365-402.

Hasani-Ranjbar S, Larijani B, Abdollahi M. A systematic review of Iranian plants useful in diabetes mellitus. Arch Med Sci, 2008; 4:285-92.

Hasani-Ranjbar S, Nayebi N, Larijani B, Abdollahi M. A systematic review of the efficacy and safety of herbal medicines used in the treatment of obesity. World J Gastroenterol, 2009; 15:3073-85.

Hegazy MEF, Elshamy AI, Mohamed TA, Hamed AR, Ibrahim MA, Ohta S, Paré PW. Cembrene diterpenoids with ether linkages from Sarcophyton ehrenbergi: an anti-proliferation and molecular-docking assessment. Mar Drugs, 2017; 15(6):192.

Ho $\mathrm{CH}$, Logakis $\mathrm{E}$, Krivda A. Influence of antioxidants in epoxy-anhydride resin used for HV applications. Proc Nordic Insulat Symp (No. 23), 2013; 9(12):57-60.

Hosseinkhani A, Ghavidel F, Mohagheghzadeh A, Zarshenas MM. Analysis of six populations of Commiphora myrrha (Nees) Engl. oleogum resin. Trends Pharm Sci, 2017; 3(1):7-12.]

Huang H, Li L, Shi W, Liu H, Yang J, Yuan X, Wu L. The multifunctional effects of nobiletin and its metabolites in vivo and in vitro. Evid Based Complement Alternat Med, 2016; 2016:1-14.

Jung H, Lim Y, Kim EK. Therapeutic phytogenic compounds for obesity and diabetes. Inter J Mol Sci, 2014; 15(11):21505-37.

Kasabri V, Al-Hallaq EK, Bustanji YK, Abdul-Razzak KK, Abaza IF, Afifi FU. Anti-obesity and anti-hyperglycaemic effects of Adiantum capillus-veneris extracts: in-vitro and in-vivo evaluations. Pharm Biol, 2017; 55(1):164-72.

Keskes H, Mnafgui K, Hamden K, Damak M, El Feki A, Allouche N. In vitro anti-diabetic, anti-obesity and antioxidant proprieties of Juniperus phoenicea L. leaves from Tunisia. Asian Pac J Trop Biomed, 2014; 4:S649-55.

Kim YS, Lee YM, Kim J, Jang DK, Kim JH, Kim JS. Antiobesity effect of Morus bombycis root extract: anti-lipase activity and lipolytic effect. J Ethnopharmacol, 2010; 130:621-4.

Kuehl GE, Lampe JW, Potter JD, Bigler J. Salicylic acid glucuronidation by expressed UGTs. Cancer Res, 2004; 2004:867.

Kusch P, Deininger S, Specht S, Maniako R, Haubrich S, Pommerening $\mathrm{T}$. In vitro and in vivo antimalarial activity assays of seeds from Balanites aegyptiaca: compounds of the extract show growth inhibition and activity against plasmodial aminopeptidase. J Parasitol Res, 2011; 2011:1-12.

Lee YS, Cha BY, Choi SS, Choi BK, Yonezawa T, Teruya T, Nagai K, Woo JT. Nobiletin improves obesity and insulin resistance in highfat diet-induced obese mice. J Nutr Bioch, 2013; 24(1):156-62.

Lei F, Zhang XN, Wang W, Xing DM, Xie WD, Su H, Du LJ. Evidence of anti-obesity effects of the pomegranate leaf extract in high-fat diet induced obese mice. Int J Obes (London), 2007; 6:1023-9.

Liolios C, Laouer H, Boulaacheb N, Gortzi O, Chinou I. Chemical composition and antimicrobial activity of the essential oil of Algerian Phlomis bovei De Noé subsp. bovei. Molecules, 2007; 12(4): $772-81$.

Liu S, Li D, Huang B, Chen Y, Lu X, Wang Y. Inhibition of pancreatic lipase, $\alpha$-glucosidase, $\alpha$-amylase, and hypolipidemic effects of the total flavonoids from Nelumbo nucifera leaves. J Ethnopharmacol, 2013; 149(1):263-9.

Mahalingam G. The in-vitro antidiabetic activity of Phoenix roebelenii leaf extract. Inter J Green Pharmacy, 2017; 11(01):S128-34.

Massoud A, El Sisi S, Salama O. Preliminary study of therapeutic efficacy of a new fasciolicidal drug derived from Commiphora molmol (myrrh). Am J Trop Med Hyg, 2001; 65(2):96-9.

Moulari B, Pellequer Y, Lboutounne H, Girard C, Chaumont JP, Millet J, Muyard F. Isolation and in vitro antibacterial activity of astilbin, the bioactive flavanone from the leaves of Harungana madagascariensis Lam. ex Poir.(Hypericaceae). J Ethnopharmacol, 2006; 106(2):272-8. 
Narkhede MB, Ajimire PV, Wagh AE, Mohan M, Shivashanmugam AT. In vitro antidiabetic activity of Caesalpina digyna (R.) methanol root extract. Asian J Plant Sci Res, 2011; 1(2):101-6.

Nićiforović N, Abramovič H. Sinapic acid and its derivatives: natural sources and bioactivity. Comp Rev Food Sci Food Saf, 2014; 13(1):34-51.

Nickavar B, Yousefian N. Inhibitory effects of six Allium species on $\alpha$-amylase enzyme activity. Iran Pharm Res, 2010; 53-7.

Nikfarjam BA, Hajiali F, Adineh M, Nassiri-Asl M. Antiinflammatory effects of Quercetin and Vitexin on activated human peripheral blood neutrophils: the effects of quercetin and vitexin on human neutrophils. J Pharmacopunc, 2017; 20(2):127.

Oboh G, Akinyimi AJ, Ademiluyi AO, Adefega SA. Inhibitory effects of aqueous extract of two varieties of ginger on some key enzymes linked to type-2 diabetes in vitro. J Food Nutr Res, 2010; 49(1):14-20.

Ouf NH, Sakran MI, Amr AEGE. Anti-inflammatory activities of some newly synthesized substituted thienochromene and Schiff base derivatives. Res Chem Intermed, 2015; 41(4):2521-36.

Pereira DF, Cazarolli LH, Lavado C, Mengatto V, Figueiredo MS, Guedes A, Pizzolatti MG, Silva FR. Effects of flavonoids on $\alpha$-glucosidase activity: potential targets for glucose homeostasis. Nutrition, 2011; 27:1161-7.

Sato A, Tamura H. High antiallergic activity of 5,6 , 4ntiallergiccosidase activity: potential targets for glucose homeostasis. Nutrition, 2011; 27:dbase dase d J Food Lam. Mentha piperita citrata). Fitoterapia, 2015; 102:74-83.

Schäfer AI, Nghiem LD, Waite TD. Removal of the natural hormone estrone from aqueous solutions using nanofiltration and reverse osmosis. Environ Sci Technol, 2003; 37(1):182-8.

Segre CAW, Hueb W, Garcia RMR, Rezende PC, Favarato D, Strunz CMC, Sprandel MD, Roggério A, de Oliveira Carvalho AL, Maranhão RC, Ramires JA. Troponin in diabetic patients with and without chronic coronary artery disease. BMC Cardiovasc Disorders, 2015; 15(1):72.

Shai LJ, Magano SR, Lebelo SL, Mogale AM. Inhibitory effects of five medicinal plants on rat alpha-glucosidase: comparison with their effects on yeast alpha-glucosidase. J Med Plants Res, 2011; 5(13):2863-7.

Sharma N, Sharma VK, Seo SY. Screening of some medicinal plants for anti-lipase activity. J Ethnopharmacol, 2005; 97:453-6.

Shen T, Wan WZ, Yuan HQ, Kong F, Guo HF, Fan PH, Lou HX. Secondary metabolites from Commiphora opobalsamum and their antiproliferative effect on human prostate cancer cells. Phytochemistry, 2007; 68(9):1331-7.

Su SL, Duan JA, Wang TJ. Distribution, chemical components and bioactivity of resin herbs: research advances. J Int Pharm Res, 2009; 36(2):109-14

Tadera K, Minami Y, Takamatsu K, Matsuoka T. Inhibition of $\alpha$-glucosidase and $\alpha$-amylase by flavonoids. J Nutr Sci Vitaminol, 2006; 52(2):149-53.

Takeda S, Hirayama A, Urata S, Mano N, Fukagawa K, Imamura M, Irii A, Kitajima S, Masuyama T, Nomiyama M, Tatei S. Cannabidiol-2', $6^{\prime}$-dimethyl ether as an effective protector of 15-lipoxygenase-mediated lowdensity lipoprotein oxidation in vitro. Biol Pharm Bull, 2011; 34(8):1252-6.

Testa R, Bonfigli A, Genovese S, De Nigris V, Ceriello A. The possible role of flavonoids in the prevention of diabetic complications. Nutrients, 2016; 8(5):310-22.
Touil YS, Auzeil N, Boulinguez F, Saighi H, Regazzetti A, Scherman D, Chabot GG. Fisetin disposition and metabolism in mice: Identification of geraldol as an active metabolite. Bioch Pharm, 2011; 82(11):1731-9.

Tschop MH, DiMarchi RD. Outstanding scientific achievement award lecture 2011: defeating diabesity: the case for personalized combinatorial therapies. Diabetes, 2012; 61:1309-14.

Ullah N, Noreen S, Tehreem K, Zaman A, Ahmad Z, Balouch H, Samad N. Liposome as nanocarrier: site targeted delivery in lung cancer. Asian Pac J Trop Dis, 2017; 7(8):502-12.

Wang Y, Yang X, Zheng X, Li J, Ye C, Song X. Theacrine, a purine alkaloid with anti-inflammatory and analgesic activities. Fitoterapia, 2010; 81(6):627-31.

Wetwitayaklung $\mathrm{P}$, Thavanapong $\mathrm{N}$, Charoenteeraboon $\mathrm{J}$. Chemical constituents and antimicrobial activity of essential oil and extracts of heartwood of Aquilaria crassna obtained from water distillation and supercritical fluid carbon dioxide extraction. Silpakorn Univ Sci Tech J, 2009; 3(1):25-33.

Wu S, Tian L. A new flavone glucoside together with known ellagitannins and flavones with anti-diabetic and anti-obesity activities from the flowers of pomegranate (Punica granatum). Nat Prod Res, 2018; 1-6.

Yajima H, Noguchi T, Ikeshima E, Shiraki M, Kanaya T, Tsuboyama-Kasaoka N, Ezaki O, Oikawa S, Kondo K. Prevention of dietinduced obesity by dietary isomerized hop extracts containing isohumulones, in rodents. Int J Obes (London), 2005; 29:991-7.

Yamamura T, Tanaka K, Tomiyama S, Sai S, Yamada F, Nishiyama T. Substituted thiobisphenols as antioxidants: correlation between antioxidant activities and13C chemical shifts. J Amer Oil Chemists' Soc, 1995; 72(9): 1047-52.

Zhang HY, Gao Y, Lai PX. Chemical composition, antioxidant, antimicrobial and cytotoxic activities of essential oil from Premna microphylla Turczaninow. Molecules, 2017; 22(3):381.

Zhang J, Kashket S. Inhibition of salivary amylase by black and green teas and their effects on the intraoral hydrolysis of starch. Caries Res, $1998 ; 32(3): 233-8$

\section{How to cite this article:}

Abdel-Hady H, El-Wakil EA, Morsi EA. Characterization of ethyl acetate and methanol extracts of Commiphora myrrha and evaluating in vitro anti-diabetic and anti-obesity activities. J Appl Pharm Sci, 2019; 9(09): $038-044$. 